\title{
Left ventricular longitudinal function in hypertensive patients with septal bulge
}

\section{Vlatka Rešković Lukšić* \\ Sanja Ceković \\ Sandra Večerić \\ Jadranka Šeparović Hanževački}

University of Zagreb School of Medicine, University Hospital Centre Zagreb, Zagreb, Croatia

\begin{abstract}
KEYWORDS: echocardiography, speckle tracking, longitudinal deformation, arterial hypertension, inerventricular septal bulge.

CITATION: Cardiol Croat. 2015;10(3-4):66. | DOI: http://dx.doi.org/10.15836/ccar.2015.66

ORCID: Vlatka Rešković Lukšić, http://orcid.org/0000-0002-4721-3236•

Sanja Ceković, http://orcid.org/0000-0003-3892-7680 • Sandra Večerić, http://orcid.org/0000-0002-8070-1012 • Jadranka Šeparović Hanževački, http://orcid.org/0000-0002-3437-6407
\end{abstract}

*ADDRESS FOR CORRESPONDENCE: Vlatka Rešković Lukšić, Klinički bolnički centar Zagreb, Kišpatićeva 12, HR-10000 Zagreb, Croatia. Phone: +385-91-561-2526. E-mail: vlatka.reskovic@gmail.com

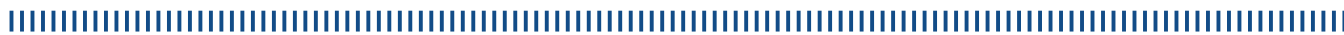

AIM: In patients with arterial hypertension, due to chronic pressure overload, structural concentric remodeling occurs. Hypertrophy pattern is determined by fiber orientation, interaction with local wall stress and is the most prominent in the region of basal interventricular septum. Every single segment deforms during systole in three dimensions - longitudinal, radial and circumferential, depending on fibers orientation. By analyzing standard echocardiographic parameters, no reduction in global ventricular function is to be found in this early phase of geometric changes, but longitudinal fibers are known to be affected and longitudinal function could already be reduced.1.-3 In this study, we wanted to investigate whether in hypertensive patients with septal bulge, there is a difference in regional longitudinal function.

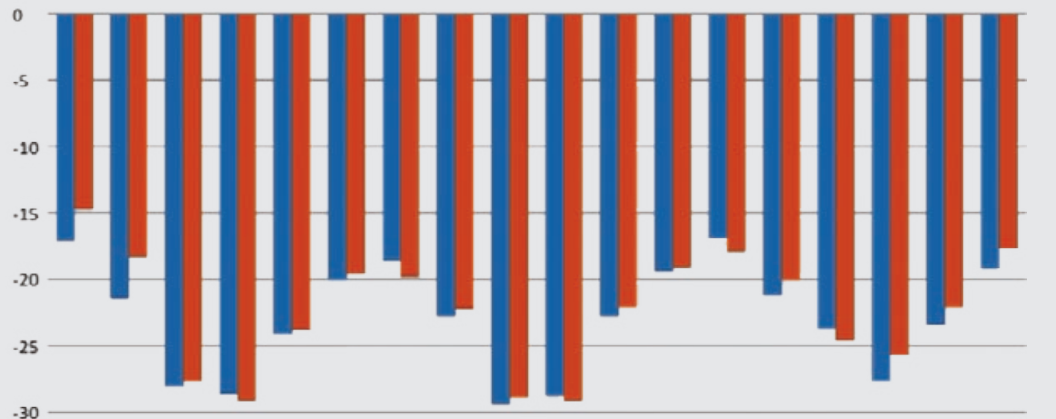

$-3$

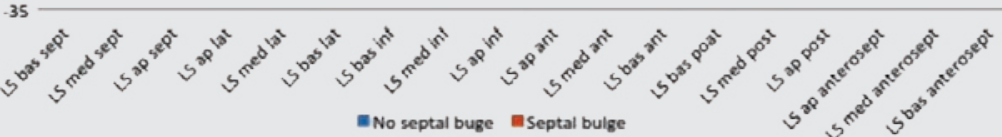

Comparation of regional longitudinal strain values between hypertensive patients with and without septal bulge.

PATIENTS AND METHODS: 30 patients with essential ar terial hypertension, no other comorbidities (valvular heart disease, coronary artery disease, diabetes mellitus, atrial fibrillation, stroke or TIA) and preserved LV ejection fraction were enrolled. Complete standard echocardiographic examination was done along with 2D speckle tracking analysis of longitudinal strain Patients were divided into two groups depending on presence of the basal interventricular (iv) septal bulge. Three patients were excluded from the study because of poor acoustic echo window In 16 patients, iv septal bulge was present, and in 11 of them was not. Regional values of longitudinal strain were measured for each LV segment and data was compared between groups.

RESULTS: In no bulge group (Figure 1), there was equal number of males ( $5 \mathrm{pts}$ ) and females ( $6 \mathrm{pts}$ ), but in septal bulge group, ma jority of patients were male (10 out of 16). There was no significant difference in patient's age between groups ( $45.7 \pm 12.9$ years in no bulge and $48.4 \pm 9.9$ years in bulge group). Mean duration of hypertension was $8.1 \pm 8.9$ years in no bulge and $6.2 \pm 8$ years in bulge group. We found no statistically significant difference in regional longitudinal strain values, except in the region of medial interventricular septum $(-21.4 \pm 3.1 \%$ vrs $-18.3 \pm 3.02 \%, P=0.26)$, which was significantly reduced in patients with basal iv septal bulge. This is the area closest to the region most prominent to pressure overload and hypertrophy and significance of this finding should be investigated further on.

RECEIVED:

April 15, 2015

ACCEPTED:

April 20, 2015

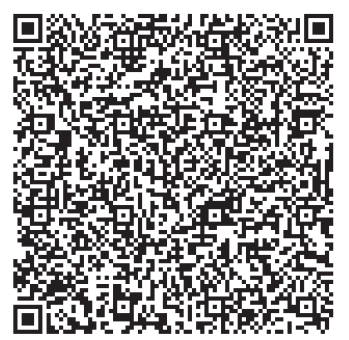

CONCLUSON: In patients with hypertension and preserved ejection fraction, even in early stages of hypertensive heart disease, subtle changes in LV longitudinal function can be found. Interventricular septal hypertrophy could be a macroscopic marker for this changes and could help us in identifying patients in greater risk for developing heart failure. This data should be confirmed on larger number of patients and with particular focus on septal segments and correlation between regional longitudinal and radial function.

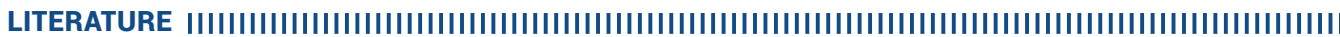

1. Baltabaeva A, Marciniak M, Bijnens B, Moggridge J, He FJ, Antonios TF, et al. Regional left ventricular deformation and geometry analysis provides insights in myocardial remodelling in mild to moderate hypertension. Eur J Echocardiogr. 2008; 9:501-8. DOI: http://dx.doi.org/10.1016/j.euje.2007.08.004

2. Narayanan A, Aurigemma GP, Chinali M, Hill JC, Meyer TE, Tighe DA, et al. Cardiac mechanics in mild hypertensive heart disease: a speckle- strain imaging study. Circ Cardiovasc Imaging. 2009;2:382-90. DOI: http://dx.doi.org/10.1161/CIRCIMAGING.108.811620

3. Mondillo S, Galderisi M, Mele D, Cameli M, Lomoriello VS, Zacà V, et al; Echocardiography Study Group Of The Italian Society Of Cardiology (Rome, Italy). Speckle-tracking echocardiography: a new technique for assessing myocardial function. J Ultrasound Med. 2011;30(1):71-83. PubMed: http://www.ncbi.nlm.nih.gov/pubmed/21193707?dopt=Abstract 